\title{
NADPH Oxidase 4
}

National Cancer Institute

\section{Source}

National Cancer Institute. NADPH Oxidase 4. NCI Thesaurus. Code C104572.

NADPH oxidase 4 ( $578 \mathrm{aa}, \sim 67 \mathrm{kDa}$ ) is encoded by the human NOX4 gene. This protein plays a role as an oxygen sensor in cell differentiation and signal transduction. 